УДК 615.2/3(477)

DOI https://doi.org/10.11603/2312-0967.2019.3.10402

\title{
РЕКОМЕНДАЦІЇ ЩОДО РОЗРОБКИ ШКАЛИ РІВНІВ ВПЛИВУ НА БЮДЖЕТ ПРИ ОЦІНЦІ ЗАКУПІВЛІ ЛІКАРСЬКИХ ЗАСОБІВ В УКРАЇНІ
}

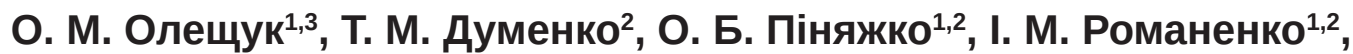 \\ М. М. Клименко ${ }^{1,2}$, О. А. Топачевський ${ }^{1}$, М. В. Лелека ${ }^{2}$
}

Експертний комітет з відбору та використання основних лікарських засобів ${ }^{1}$ Державний Експертний центр МОЗ України ${ }^{2}$, Київ

Тернопільський національний медичний університет імені І. Я. Горбачевського МОЗ України ${ }^{3}$

oleshchuk@tdmu.edu.ua

\section{ІНФОРМАЦІЯ}

Надійшла до редакції / Received: 23.08.2019

Після доопрацювання / Revised: 27.08.2019

Прийнято до друку / Accepted: 29.08.2019

\section{Ключові слова:}

оцінка медичних технологій; аналіз впливу на бюджет; Національний перелік основних лікарських засобів;

лікарські засоби.

\section{АНОТАЦІЯ}

Мета роботи. Розробка шкали рівнів впливу на бюджет при оцінці включення лікарського засобу до Національного переліку основних лікарських засобів (Національного переліку) під час аналізу економічної ефективності лікарських засобів (ЛЗ).

Матеріали і методи. 3 використанням ABC-аналізу розроблено рекомендації 3 оцінки потенційного впливу на бюджет лЗ у разі його включення до Національного переліку. В дослідженні використано дані, представлені системою дослідження ринку «Фармексплорер», Support in Market Development (SMD) за 2018 рік.

Результати й обговорення. Розроблену шкалу рівнів впливу на бюджет рекомендовано використовувати для оцінки фрінансових наслідків застосування медичної технології протягом відповідного часового горизонту - на один та більше років для забезпечення належного рівня фрункціонування у сорері охорони здоров'я. Якщо витрати на одну міжнародну непатентовану назву (МHН) при закупівлі за кошти державного та місцевого бюджетів перевищують 40 млн грн на рік, то вплив на бюджет буде надмірний. Якщо витрати на одну МНН знаходяться в межах від 20 до 40 млн грн, то вплив на бюджет - великий, якщо витрати становлять від 10 до 20 млн грн - помірний, а менше 10 млн грн - незначний. При умові включення Л3 до Національного переліку для закупівлі закладами та установами охорони здоров'я, що фрінансуються з місцевих бюджетів, шкала рівнів впливу на бюджет має таку градацію: якщо витрати на одну МНH перевищують 17 млн грн на рік, то вплив на бюджет буде надмірний, в межах від 6 до 17 млн грн - великий, в межах від 3 до 6 млн грн - помірний, менше 3 млн - незначний.

Висновки. На основі проведеного аналізу закупівель Лз з Національного переліку за 2018 рік розроблено шкалу рівнів впливу на бюджет, яка має таку градацію за чотирма рівнями впливу: надмірний, великий, помірний та незначний. Перспективним є використання шкали рівнів впливу на бюджет при оцінці медичних технологій з метою їхнього подальшого фрінансування за кошти державного та місцевих бюджетів в Україні.

ISSN 2312-0967. Фармацевтичний часопис. 2019. № 3 
Вступ. Відбір основних лікарських засобів (ЛЗ) є одним 3 ключових елементів Державної стратегії реалізації державної політики забезпечення населення лікарськими засобами на період до 2025 року, затвердженої Постановою Кабінет Міністрів України від 5 грудня 2018 р. № 1022 «Про затвердження Державної стратегії реалізації державної політики забезпечення населення лікарськими засобами на період до 2025 року» [1]. Метою відбору є наявність таких ЛЗ у закладах охорони здоров'я у необхідній кількості для забезпечення належного рівня функціонування системи охорони здоров'я (О3). 3 появою нових високовартісних технологій у сорері ОЗ в Україні виникла потреба у створенні та впровадженні цілісної системи відбору Л3, що була б заснована на оцінці медичних технологій (ОМТ). Такий підхід використовується в розвинених країнах у процесі вибору ЛЗ для включення в регуляторні (позитивні) переліки з метою їхнього раціонального ефективного фрінансування та розподілу ресурсів.

Проблему відбору основних ЛЗ передбачається розв'язати шляхом регулярного оновлення Національного переліку основних лікарських засобів (Національний перелік) за принципами прозорості та відкритості процесу відбору із застосуванням ОМТ 3 урахуванням пріоритетності фрінансування для хвороб та патологічних станів, доказів порівняльної ефективності (результативності), безпеки, фрінансових наслідків для системи О3 та доступності Л3, а також галузевих стандартів у сфері ОЗ та рівня фрінансування медичної допомоги [2, 3].

Доступність Л3, що є одним 3 напрямків діяльності Кабінету Міністрів України, визначених у середньостроковому плані пріоритетних дій Уряду до 2020 року, затвердженому розпорядженням Кабінету Міністрів України від 3 квітня 2017 р. № 275 «Про затвердження середньострокового плану пріоритетних дій Уряду до 2020 року та плану пріоритетних дій уряду на 2017 рік», передбачено забезпечувати також шляхом підвищення доступності для населення інноваційних (високовартісних) Л3 [4].

Членами Експертного комітету з відбору та використання основних лікарських засобів (Експертний комітет) у співробітництві з експертами департаменту оцінки медичних технологій Державного експертного центру МОЗ України розроблено рекомендації 3 оцінки потенційного впливу на бюджет лз у разі включення у Національний перелік.

Аналіз впливу на бюджет системи ОЗ в Україні дозволяє всебічно оцінити наслідки прийняття рішення про фрінансування медичної технології за державні кошти. Аналіз впливу на бюджет слід проводити 3 перспективи організації/установи, яка зобов'язана фрінансувати послуги за кошти державного та місцевих бюджетів, а у випадку спільного фрінансування оплата, із спільної перспективи платників: державний платник і пацієнти. Якщо немає співоплати, або вона незначна від пацієнта, тоді можна використовувати лише перспективу державного платника.

Ми проаналізували досвід провідних міжнародних організацій з ОМТ щодо використання шкали впливу на бюджет. Встановлено, що за рекомендацією експертів Національного інституту охорони здоров'я і досконалості медичної допомоги (National Institute for Health and Care Excellence, NICE) необхідними умовами впровадження нової технології для використання в національній системі ОЗ є: оптимізація керування доступом до нових Лз та медичних технологій шляхом оцінки впливу на бюджет; забезпечення умов, які заохочують індустрію та науковців працювати разом в інтересах пацієнтів [5 - 8].

Мета роботи - розробка шкали рівнів впливу на бюджет у разі включення ЛЗ до Національного переліку.

Матеріали і методи. АВС-аналіз - один із варіантів математично-статистичних методів аналізу ЛЗ за трьома категоріями (А, В і C) відповідно до вартості їхнього щорічного використання. На підставі результатів ABC-аналізу можна приймати адміністративні та управлінські рішення, визначати заходи для покращення використання ЛЗ, виключати/включати певні ЛЗ до регуляторного переліку ЛЗ, таким чином оновлюючи його [9 - 11].

Наведено два сценарії, враховуючи рівні бюджету для покриття Національного переліку та характер показників (статистичні чи математичні), що використовувались при розрахунках: сценарій 1 включає в себе АВС-аналіз закупівель за рахунок державного та місцевого бюджету Л3, які включені в Національний перелік; сценарій 2 включає в себе АВС-аналіз закупівель за рахунок місцевого бюджету лз, які включені в Національний перелік.

Результати й обговорення. Проведення оцінки рівня впливу на бюджет у разі включення ЛЗ до Національного переліку складалось 3 декількох етапів.

Етап 1. Ідентифрікація. Проведено збір релевантних вхідних даних, попередні розрахунки та фрормування основної таблиці з визначенням питомої ваги витрат на кожну МНН в загальних витратах бюджету Національного переліку. Для цього було використано наступні джерела даних: система дослідження ринку «Фармексплорер», Support in Market Development (SMD) за 2018 рік. Вибірка включала такі показники: наявність в Національному переліку, МНH, торговельна назва, повна назва та інформація щодо упаковки, дозування, фрорми випуску, кількість упаковок, розмір витрат (грн).

Наступний крок - розрахунок суми витрат по одній МНH (якщо за однією МНН закуповувались декілька торговельних назв); проведено ранжування Л3 за сумою витрат, починаючи з найбільшого значення; визначення питомої ваги витрат на кожен лз (відношення витрат на досліджуваний лз до витрат на всі закуплені Л3); визначення суми часток витрат (кумулятивної частки), середнє значення, медіану.

ISSN 2312-0967. Pharmaceutical review. 2019. № 3 
Етап 2. Категоризація. На цьому етапі аналізу проведено визначення МНH, що складають основну (найбільш витратну) частину даного бюджету. Результати аналізу наведено в таблиці 1 та на рисунку 1, де представлені закупівлі Л3 з Національного переліку за кошти державного та місцевих бюджетів (сценарій 1) за 2018 рік. За даними таблиці 1, до найбільш витратної групи (А) входить $84 \mathrm{MHH}$, що становить $24 \%$ від усіх МНН. Витрати групи А становлять 4906030000 грн, середня ціна однієї МНН становить 58405000 грн.

Наступним кроком було проведення аналізу закупівель за кошти місцевого бюджету лз, які включені в Національний перелік (сценарій 2). За даними таблиці 2 та рисунка 2, до найбільш витратної групи (A) входить $51 \mathrm{MHH}$, що становить $16 \%$ від усіх МНH. Витрати групи А становлять 1553255935 грн, середня ціна однієї МНН становить 30455999 грн.

Наступним, третім етапом дослідження, є аналіз даних з метою визначення градації (в грошовому еквіваленті), за якою будуть визначатися рівні впливу на бюджет. 3 цією метою була обрана група A та B проведеного ABC-аналізу. 3 метою встановлення валідних показників використано характеристики математичної статистики квантиль, квартиль, медіана. Методами, що вказують на розташування розподілу, прийнято вважати середнє, медіану та моду. Крім цього, як додаткові методи використовують процентилі та квантилі. Квантилі характеризують розподіл більш детально. Найпопулярніші квантилі - 25 \% та $75 \%$. Міжквантильний розкид оцінюється як різниця між $25 \%$ та $75 \%$ квантилями [12]. 0,2-квантиль називається першим (або нижнім) квартилем; 0,5-квантиль називається медіаною або другим квартилем; 0,75-квантиль називається третім (або верхнім) квартилем. Квартилі - це варіанти, які поділяють обсяги сукупності на чотири рівні частини [13]. Ці характеристики визначаються на основі кумулятивних частот (часток) за аналогією з медіаною, яка $є$ другим квартилем - оскільки рівно 50 \% значень знаходяться до другого квартиля і 50 \% значень - після другого квартиля. Виділяють перший (Q1), другий (Q2) і третій квартиль (Q3).

Аналіз закупівель за кошти державного та місцевих бюджетів Л3, які включені до Національному переліку (група А та В), передбачав визначення середнього значення, медіани, максимального значення та квартилів. Результати представлено у таблиці 3. За даними таблиці 3, при закупівлі ЛЗ за кошти державного та місцевих бюджетів, вартість однієї МНН має такі значення: середнє - 34621000 грн, медіана - 19551003 грн, максимальне значення - 309445436 грн.

\section{Таблиця 1}

Результати ABC-аналізу закупівель за кошти державного та місцевих бюджетів лікарських засобів, які включені в Національний перелік

\begin{tabular}{|l|l|l|l|l|l|}
\hline \multicolumn{1}{|c|}{ Група } & $\begin{array}{c}\text { Відсоток } \\
\text { витрат }\end{array}$ & \multicolumn{1}{|c|}{ МНH, к-ть } & \multicolumn{1}{|c|}{ МHН, \% } & \multicolumn{1}{c|}{ Сума (всі МНH), грн } & $\begin{array}{c}\text { Середня ціна однієї } \\
\text { МНН, грн }\end{array}$ \\
\hline А & 80,0 & 84 & 24,0 & 4906030000,0 & 58405000,0 \\
\hline В & 15,0 & 85 & 24,0 & 919881000,0 & 10822000,0 \\
\hline C & 5,0 & 183 & 52,0 & 306627000,0 & 1676000,0 \\
\hline
\end{tabular}

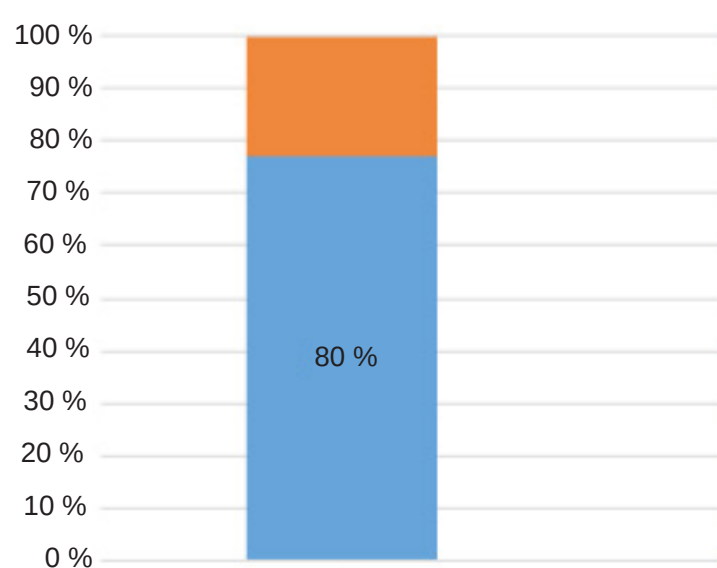

A

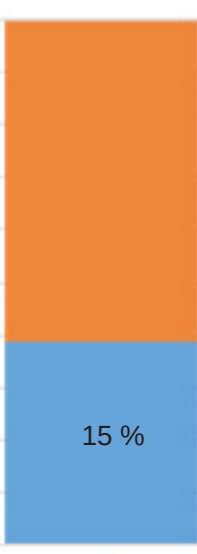

B

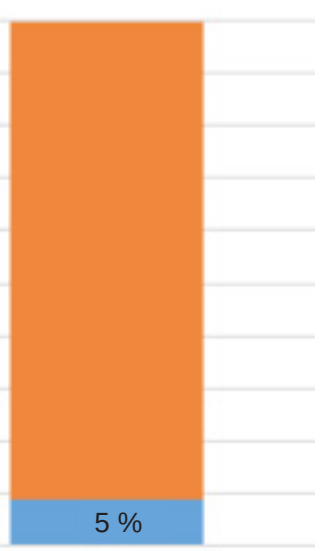

C

\% витрат ш

Рис. 1. Результати ABC - аналізу закупівель за кошти державного та місцевого бюджету лікарських засобів, які включені в Національний перелік.

ISSN 2312-0967. Фармацевтичний часопис. 2019. № 3 


\section{Таблиця 2}

Результати АВС - аналізу закупівель лікарських засобів, які включені в Національний перелік за кошти місцевого бюджету

\begin{tabular}{|c|c|c|c|c|c|}
\hline Група & $\begin{array}{l}\text { Відсоток } \\
\text { витрат }\end{array}$ & $\mathrm{MHH}$ & $\mathrm{MHH}, \%$ & Сума (всі МНH), грн & $\begin{array}{c}\text { Середня ціна однієї } \\
\text { МНН, грн }\end{array}$ \\
\hline A & 80,0 & 51 & 16,0 & 1553255935,0 & 30455999,0 \\
\hline B & 15,0 & 67 & 21,0 & 291235488,0 & 4346798,0 \\
\hline $\mathrm{C}$ & 5,0 & 205 & 63,0 & 97078496,0 & 473554,0 \\
\hline
\end{tabular}

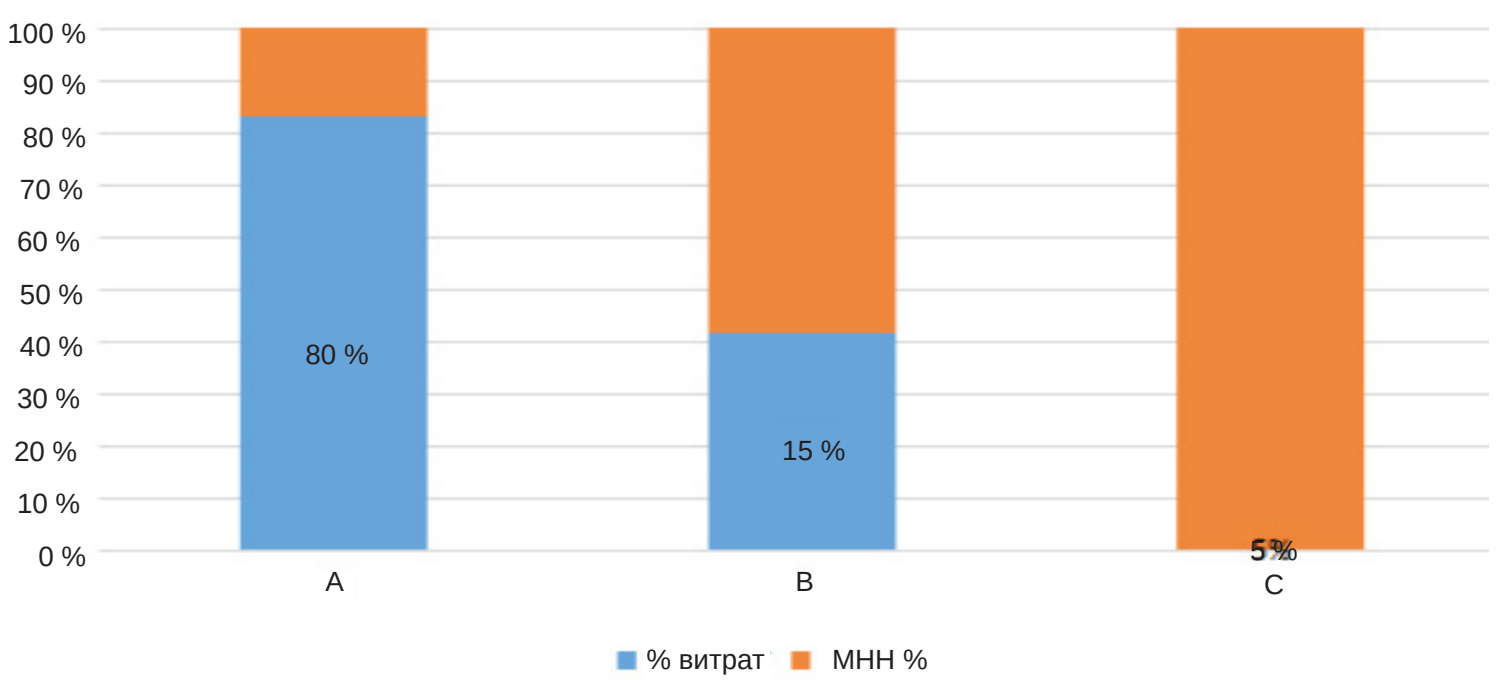

Рис. 2. Результати ABC - аналізу закупівель за кошти місцевого бюджету лікарських засобів, які включені в Національний перелік.

Аналіз закупівель за кошти місцевого бюджету лз, які включені в Національний перелік (група А та В), та статистичні показники представлені в таблиці 4. 3а даними таблиці 4, при закупівлі Л3 за кошти місцевого бюджету, вартість однієї МНH має такі значення: середнє - 15699792 грн, медіана - 6272857 грн, максимальне значення - 122805973 грн.

Наступним етапом було створення шкали рівнів впливу на бюджет. При вивченні розподілів групи статистики використовують міжквантильний розкид, який оцінюється як різниця між 25 \% (відповідає першому квартилю Q1) та 75 \% квантилями (відповідає третьому квартилю Q3).
Таким чином, провівши аналіз даних системи дослідження ринку «Фармексплорер», Support in Market Development (SMD) за 2018 рік щодо Л3, які наявні в Національному переліку та закуповувались за кошти державного та місцевих бюджетів, враховуючи статистичні показники, отримано дані, представлені в таблицях 5 та 6.

Відповідно до сценарію 1 (закупівлі за кошти державного та місцевих бюджетів ЛЗ, які включені в Національний перелік) встановлено наступні рівні впливу на бюджет: надмірний - якщо сума витрат на одну МНН перевищує 39637410 грн, великий - якщо сума витрат знаходиться в межах від

\section{Таблиця 3}

Статистичні показники при аналізі груп А та В закупівель за кошти державного та місцевих бюджетів лікарських засобів, які включені в Національний перелік

\begin{tabular}{|c|c|c|c|c|c|}
\hline Середнє, грн & Медіана, грн & $\max$, грн & Q1, грн & Q2, грн & Q3, грн \\
\hline 34621000,0 & 19551003,0 & 309445436,0 & 10008143,0 & 19551003,0 & 39637410,0 \\
\hline
\end{tabular}

\section{Таблиця 4}

Статистичні показники при аналізі груп А та В закупівель за кошти місцевого бюджету лікарських засобів, які включені в Національний перелік

\begin{tabular}{|c|c|c|c|c|c|}
\hline Середнє, грн & Медіана, грн & $\max$, грн & Q1, грн & Q2, грн & Q3, грн \\
\hline 15699792,0 & 6272857,0 & 122805973,0 & 3748434,0 & 6272857,0 & 17093368,0 \\
\hline
\end{tabular}

ISSN 2312-0967. Pharmaceutical review. 2019. № 3 
Фармакоекономіка

Pharmacoeconomics

\section{Таблиця 5}

Рівні впливу на бюджет при закупівлі за кошти державного та місцевого бюджету лікарських засобів, які включені в Національний перелік

\begin{tabular}{|l|l|}
\hline \multicolumn{2}{|c|}{ За розподілом МНН на основі статистичних показників (медіана та квартилі) } \\
\hline \multicolumn{2}{|c|}{ Рівні впливу } \\
\hline Надмірний грн \\
\hline Великий & $>39637410$ \\
\hline Помірний & $>19551003 \leq 39637410$ \\
\hline Незначний & $>10008143 \leq 19551003$ \\
\hline
\end{tabular}

\section{Таблиця 6}

Рівні впливу на бюджет при закупівлі за кошти місцевого бюджету лікарських засобів, які включені в Національний перелік

\begin{tabular}{|l|l|}
\hline \multicolumn{2}{|c|}{ За розподілом МНН на основі статистичних показників (медіана та квартилі) } \\
\hline \multicolumn{1}{|c|}{ Рівні впливу } & \multicolumn{1}{|c|}{ Сума, грн } \\
\hline Надмірний & $>17093368$ \\
\hline Великий & $>6272857 \leq 17093368$ \\
\hline Помірний & $>3748434 \leq 6272857$ \\
\hline Незначний & $\leq 3748434$ \\
\hline
\end{tabular}

19551003 до 39637410 грн, помірний - якщо сума витрат знаходиться в межах від $10008143 \leq$ 19551003 та незначний - при витратах менше/ рівно 10008143 грн.

Сценарій 2 - закупівлі за кошти місцевого бюджету л3, які включені в Національний перелік. Таким чином, відповідно до сценарію 2 встановлено наступні рівні впливу на бюджет: надмірний - якщо сума витрат на одну МНH перевищує 17093368 грн, великий - якщо сума витрат знаходиться в межах від $6272857 \leq 17093368$ грн, помірний - якщо сума витрат знаходиться в межах від $3748434 \leq$ 6272857 грн та незначний - при витрата менше/рівно 3748434 грн.

Також був застосований підхід, при якому рівні впливу на бюджет були розраховані на основі математичних показників. Етапи I, II, III (збір вхідних даних, попередні розрахунки, фрормування основної таблиці, АВС-аналіз) були аналогічними тим, що вкладені вище. Замість розрахунку медіани та квартилів, було розраховане середнє значення вартості однієї МHН, яке становить для групи $\mathrm{A}$ 58405000 грн, для групи В - 10822000 грн, для групи С - 1676000 грн.

Ми розробили рекомендації щодо рівнів впливу на бюджет при проведенні ОМТ лЗ для включення до Національного переліку. При умові включення л3 в Національний перелік для закупівлі закладами та установами охорони здоров'я, що фінансуються 3 державного та місцевих бюджетів, визначено шкалу рівнів впливу на бюджет. Якщо витрати на одну МНH перевищують 40 млн грн на рік, то вплив на бюджет буде надмірний. Якщо витрати на одну МНH знаходяться в межах від 20 млн до 40 млн, то вплив на бюджет великий, якщо витрати становлять від 10 до 20 млн грн, то вплив помірний, якщо витрати менше 10 млн, то вплив незначний.

Провівши аналіз міжнародних публікацій, ми визначили, що для прикладу, у Великобританії у 2016 році встановлено поріг у 20 млн фрунтів стерлінгів. Якщо витрати на нову технологію за будьякий 3 перших трьох років перевищують це значення, то держава не може її фрінансувати без втрат при фрінансуванні інших технологій. У таких випадках міжнародна практика використовує переговорні процедури з фармацевтичними компаніями щодо оптимізації ціноутворення та розглядаються варіанти поступового введення нової технології.

При умові включення ЛЗ в Національний перелік для закупівлі закладами та установами охорони здоров'я, що фрінансуються з місцевих бюджетів, визначено шкалу рівнів впливу на бюджет: якщо витрати на одну МНН перевищують 17 млн грн на рік, то вплив на бюджет буде надмірний. Якщо витрати на одну МНН знаходяться в межах від 6 млн грн до 17 млн грн, то вплив на бюджет великий, якщо витрати становлять від 3 до 6 млн грн, то вплив помірний, якщо витрати менше 3 млн, то вплив незначний.

Перегляд рівнів впливу на бюджет рекомендовано проводити щорічно після аналізу рівнів витрат бюджету на покриття Національного переліку за попередній рік у разі включення лЗ до Національного переліку.

ISSN 2312-0967. Фармацевтичний часопис. 2019. № 3 


\section{Таблиця 7}

Шкала для визначення рівня впливу на бюджет при закупівлі за кошти державного та місцевих бюджетів лікарських засобів, які включені в Національний перелік

\begin{tabular}{|l|l|}
\hline \multicolumn{1}{|c|}{ Рівні впливу } & \multicolumn{1}{c|}{ Сума, грн } \\
\hline Надмірний & $>40000000$ \\
\hline Великий & $>20000000 \leq 40000000$ \\
\hline Помірний & $>10000000 \leq 20000000$ \\
\hline Незначний & $\leq 10000000$ \\
\hline
\end{tabular}

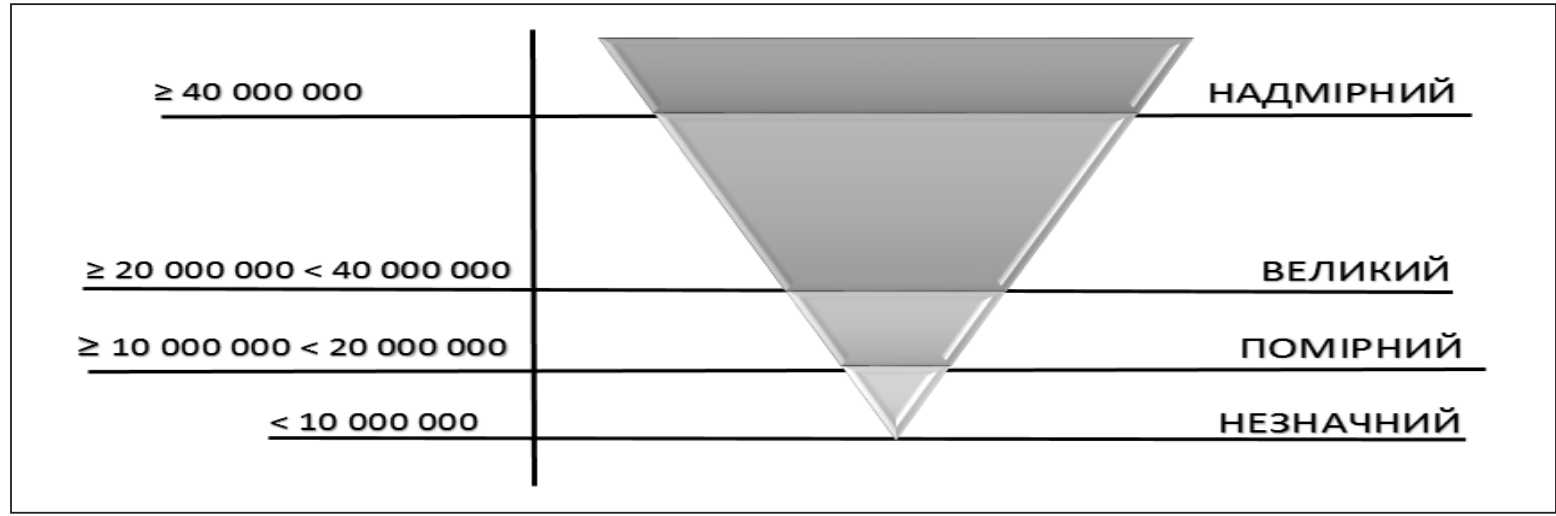

Рис. 4. Визначення рівня впливу на бюджет при закупівлі за кошти державного та місцевих бюджетів лікарських засобів, які включені в Національний перелік (грн).

\section{Таблиця 8}

Шкала для визначення рівня впливу на бюджет при закупівлі за кошти місцевого бюджету лікарських засобів, які включені в Національний перелік

\begin{tabular}{|l|l|}
\hline \multicolumn{1}{|c|}{ Рівні впливу } & \multicolumn{1}{c|}{ Сума, грн } \\
\hline Надмірний & $>17000000$ \\
\hline Великий & $>6000000 \leq 17000000$ \\
\hline Помірний & $>3000000 \leq 6000000$ \\
\hline Незначний & $\leq 3000000$ \\
\hline
\end{tabular}

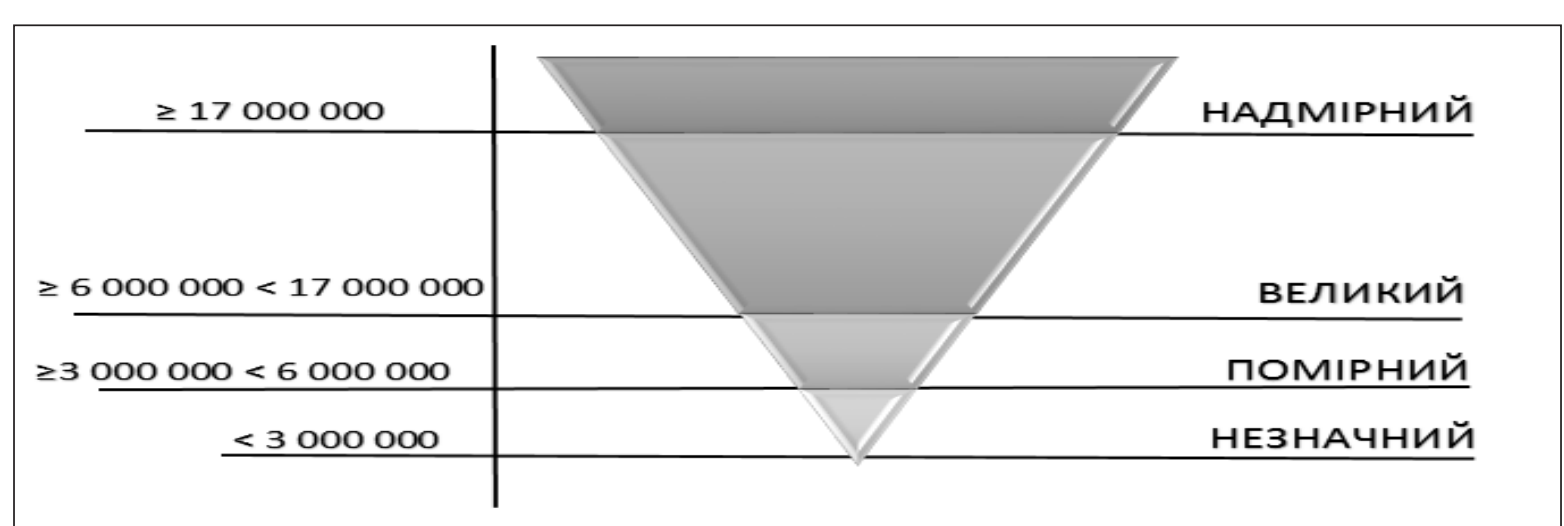

Рис. 5. Визначення рівня впливу на бюджет при закупівлі за кошти місцевого бюджету лікарських засобів, які включені в Національний перелік (грн).

Висновки. Розроблено методичні підходи та рекомендації щодо визначення рівнів впливу на бюджет у разі включення Л3 до Національного переліку залежно від джерел фрінансування. Розроблено шкалу для визначення рівня впливу на бюджет при ОМТ для включення Л3 в Національний перелік для закупівлі закладами та установами охорони здоров'я, що фрінансуються 3 державного та місцевих бюджетів.

ISSN 2312-0967. Pharmaceutical review. 2019. № 3 
Встановлено, що надмірний рівень впливу на бюджет при фрінансуванні $з$ державного та місцевих бюджетів складає понад 40 млн грн, а при фрінансуванні 3 місцевих бюджетів цей поріг становить 17 млн грн. У випадку перевищення цих показників міжнародна практика використовує переговорні процедури з фармацевтичними компаніями щодо оптимізації ціноутво- рення. Перспективним $€$ використання шкали впливу на бюджет при ОМТ з метою їх подальшого фрінансування/реімбурсації за кошти державного і місцевих бюджетів.

Конфлікт інтересів: відсутній.

Conflicts of interest: authors have no conflict of interest to declare.

\title{
RECOMMENDATIONS CONCERNING DEVELOPMENT OF THE SCALE OF BUDGET IMPACT RATE IN THE EVALUATION OF THE PURCHASE OF MEDICINES IN UKRAINE
}

\author{
O. M. Oleschuk ${ }^{1,3}$, T. M. Dumenko', O. B Pinyazhko ${ }^{1,2}$, I. M. Romanenko ${ }^{1,2}$, M. M. Klymenko ${ }^{1,2}$, \\ O. A. Topachevsky ${ }^{1}$, M. V. Leleka ${ }^{2}$
}

Expert Committee on Selection and Use of Essential Medicines ${ }^{1}$, Kyiv

State Expert Center of the Ministry of Health of Ukraine ${ }^{2}$, Kyiv

I. Horbachevsky Ternopil National Medical University ${ }^{3}$, Ternopil

oleshchuk@tdmu.edu.ua

The aim of the work. Development of a rate of budget impact when evaluating the inclusion of a medicines on the National List of Essential Medicines (National List) in the analysis of the economic efficiency.

Materials and Methods. ABC analysis was used for development of this recommendations to assess the potential impact on the budget of the drug if it is included in the National List. The study used data provided by the Pharmexsplorer market research system, Support in Market Development (SMD) for 2018.

Results and Discussion. The developed scale of rate of budget impact is recommended to be used to assess the financial consequences of using medical technology over an appropriate time horizon of 1 year or more to ensure an adequate level of functioning in the healthcare sector. In the case of procurement by state budget and local budgets, if expenses per one INN exceeds 40 million UAH per year, the budget impact rate is excessive. If the expenses for one INN are in the range from 20 million to 40 million, the budget impact rate is big, if the costs range from 10 to 20 million UAH, then the impact is moderate, if expenses are less than 10 million, then the impact is insignificant.

Subject to the inclusion of a medicinal product in the National List, in the case of procurement by health care institutions that are financed from the local budget, the scale of budget impact levels has the following gradation: if the cost per INN exceeds 17 million UAH per year, the budget impact rate is excessive. If the expenses for one INN are in the range from 6 to 17 million $\mathrm{UAH}$, the budget impact rate is big, if the expenses for one INN are in the range from 3 to 6 million $\mathrm{UAH}$, the impact is moderate; if the expenses are less than 3 million, the impact is insignificant.

Conclusions. A scale for determining of rate of budget impact was developed based on the analysis of the procurement of medicines from the National List for 2018. It has such a gradation in four levels of influence: excessive, big, moderate and insignificant. It is promising to use a rate of budget impact with the aim of future financing by the expenses of state and local budgets in Ukraine.

\section{РЕКОМЕНДАЦИИ ПО РАЗРАБОТКЕ ШКАЛЫ УРОВНЕЙ ВЛИЯНИЯ НА БЮДЖЕТ ПРИ ОЦЕНКЕ ЗАКУПОК ЛЕКАРСТВЕННЫХ СРЕДСТВ В УКРАИНЕ}

\author{
А. М. Олещук $\kappa^{1,3}$, Т. Н. Думенко ${ }^{2}$, О. Б. Пиняжко ${ }^{1,2}$, И. Н. Романенко ${ }^{1,2}$, М. Н. Клименко ${ }^{1,2}$,
} А. А. Топачевский ${ }^{1}$ М. В. Лелека ${ }^{2}$

Экспертный комитет по отбору и использованию основных лекарственных средств МОЗ Украины ${ }^{1}$, Киев

Государственный Экспертный центр МОЗ Украины ${ }^{2}$, Киев

Тернопольский национальный медицинский университет имени И. Я. Горбачевского МОз Украинь ${ }^{3}$, Тернополь

oleshchuk@tdmu.edu.ua

Цель работы. Разработка шкалы уровней влияния на бюджет при оценке включения лекарственного средства в Национальный перечень основных лекарственных средств (Национальный перечень) при анализе экономической эсрфективности лекарственных средств (ЛС).

ISSN 2312-0967. Фармацевтичний часопис. 2019. № 3 
Материалы и методы. С использованием АВС-анализа разработаны рекомендации по оценке потенциального влияния на бюджет лС в случае его включения в Национальный перечень. В исследовании использованы данные, предоставленные системой исследования рынка «Фармэксплорер», Support in Market Development (SMD) по 2018.

Результаты и обсуждение. Разработанную шкалу уровней влияния на бюджет рекомендуется использовать для оценки финансовых последствий использования медицинской технологии в течение соответствующего временного горизонта - на 1 год и более для обеспечения надлежащего уровня функционирования в сфере здравоохранения. Если расходы на одно международное непатентированное название (МНH) при закупке за средства государственного и местного бюджетов превышают 40 млн грн в год, то влияние на бюджет будет избыточным. Если расходы на одно МНН находятся в пределах от 20 млн до 40 млн грн, то влияние на бюджет большое, если расходы составляют от 10 до 20 млн грн - умеренное, а меньше 10 млн грн - незначительное. При условии включения лекарственного средства в Национальный перечень в случае приобретения учреждениями здравоохранения, фринансируемых из местных бюджетов, шкала уровней влияния на бюджет имеет такую градацию: если расходы на одну МНН превышают 17 млн грн в год, то влияние на бюджет будет чрезмерным, в пределах от 6 до 17 млн грн - большим, в пределах от 3 до 6 млн грн - умеренным, меньше 3 млн - незначительным

Выводы. На основе проведенного анализа закупок лекарственных средств из Национального перечня за 2018 год разработана шкала уровней влияния на бюджет, которая имеет такую градацию по четырем уровням влияния: чрезмерное, большое, умеренное и незначительное. Перспективным является использование шкалы уровней влияния на бюджет при оценке медицинских технологий с целью их дальнейшего фринансирования за счет государственного и местных бюджетов в Украине.

Ключевые слова: оценка медицинских технологий; анализ влияния на бюджет; национальный перечень основних лекарственных средств; лекарственные средства.

Key words: health technology assessment; budget impact rate; national list of essential medicines; medicines.

\section{Список літератури}

1. Про затвердження Державної стратегії реалізації державної політики забезпечення населення лікарськими засобами на період до 2025 року : Постанова КМУ від 5 грудня 2018 р. № 1022. - Режим доступу : https://zakon.rada.gov.ua/laws/show/10222018-\%D0\%BFhttps://zakon.rada.gov.ua/laws/show/ z0258-16.

2. Про затвердження середньострокового плану пріоритетних дій Уряду до 2020 року та плану пріоритетних дій Уряду на 2017 рік : Розпорядження КМУ від 3 квітня 2017 р. № 275-р. - Режим доступу : https://zakon.rada.gov.ua/laws/show/275-2017$\%$ D1\%80\#n10

3. Про затвердження Положення про Національний перелік основних лікарських засобів та Положення про експертний комітет з відбору та використання основних лікарських засобів : наказ МОЗ України 11.02.2016 № 84. - Режим доступу : https://zakon. rada.gov.ua/laws/show/z0258-16.

4. Керівна настанова із оцінки технологій охорони здоров'я, Експертний комітет 3 відбору та використання основних лікарських засобів МОЗ України, Версія 1.1. - Київ, 2018.

5. Budget impact test (NICE). Access mode : [https://www. nice.org.uk/about/what-we-do/our-programmes/niceguidance/nice-technology-appraisal-guidance/budgetimpact-test.

6. Budget Impact Analysis-Principles of Good Practice: Report of the ISPOR 2012 Budget Impact Analysis
Good Practice II Task Force / Sean D. Sullivan, Josephine A. Mauskopf, Federico Augustovski [et al.] // Value in Health. - 2014. - Vol. 17, Issue 1. - P. 5-14. Access mode : https://doi.org/10.1016/j.jval.2013.08.2291.

7. Principles of Good Practice for Budget Impact Analysis: Report of the ISPOR Task Force on Good Research Practices- Budget Impact Analysis / Josephine A. Mauskopf, Sean D. Sullivan, Lieven Annemans [at al.] // Value in Health. - 2007. - Vol. 10. - No. 5. - P. 336-347. Access mode : [https://doi.org/10.1111/ j.1524-4733.2007.00187.x]

8. Drug and Therapeutics Committees - A Practical Guide I World Health Organization. - 2003. - Access mode : http://apps.who.int/medicinedocs/es/d/Js4882e/12. html]

9. Management Sciences for Health and World Health Organization. 2007. Drug and Therapeutics Committee Training Course. Submitted to the U.S. Agency for International Development by the Rational Pharmaceutical Management Plus Program. Arlington, VA: Management Sciences for Health.

10. Економічний аналіз використання ресурсів в системі охорони здоров'я / Парій В. Д., Сафонов Ю. М., Захарова Н. М. та ін. / За загальною редакцією профессора В. Д. Парія. - Житомир : «Полісся», 2015. $142 \mathrm{c}$.

11. Методичні рекомендації 3 оцінки клінічної та економічної доцільності використання лікарських засобів у лікувально-профрілактичному закладі

ISSN 2312-0967. Pharmaceutical review. 2019. № 3 
(супровід фрормулярної системи) / Морозов А. М., Яковлєва Л. В., Бездітко Н. В. [та ін.]. - Харків : Видво НФаУ, 2012. - 59 с

12. Бідюк П. І. Прикладна статистика / П. І. Бідюк, О. М. Терентьєв, Т. І. Просянкіна-Жарова. - Вінниця :

\section{References}

1. Decree of the Cabinet of Ministers 12/05/2018 p. No 1022. On Approval of the State Strategy for the Implementation of the State Policy of Providing the Population with Medicines for the period up to 2025 [Про затвердження Державної стратегії реалізації державної політики забезпечення населення лікарськими засобами на період до 2025 року]. Available from: https://zakon.rada.gov.ua/laws/show/1022-2018\%D0\%BFhttps://zakon.rada.gov.ua/laws/show/z025816. Ukrainian.

2. Order of the Ministry of Health of Ukraine 02/11/2016 № 84. On Approval of the Regulation on the National List of Essential Medicines and the Regulation of the Expert Committee of Selection and Use of Essential Medicines [Про затвердження Положення про Національний перелік основних лікарських засобів та Положення про експертний комітет з відбору та використання основних лікарських засобів]. Available from: https://zakon.rada.gov.ua/laws/show/z0258-16]. Ukrainian.

3. Guidelines for the health technology assessment, Expert Committee on the selection and use of essential medicines of the Ministry of Health of Ukraine, Version 1.1. [Керівна настанова із оцінки технологій охорони здоров'я, Експертний комітет з відбору та використання основних лікарських засобів МОЗ України, Версія 1.1.] Kyiv; 2018. Ukrainian.

4. Order of the Ministry of Health of Ukraine on 04/03/2017. № 275-p. On approval of the medium-term plan of the Government's priority actions by 2020 and the plan of the Government's priority actions for 2017. [Про затвердження середньострокового плану пріоритетних дій Уряду до 2020 року та плану пріоритетних дій Уряду на 2017 рік] Available from: https://zakon.rada. gov.ua/laws/show/275-2017-\%D1\%80\#n10. Ukrainian.

5. Budget impact test (NICE). Available from: https://www. nice.org.uk/about/what-we-do/our-programmes/niceguidance/nice-technology-appraisal-guidance/budgetimpact-test.

6. Budget Impact Analysis - Principles of Good Practice:
ПП «ТД»Едельвейс і К», 2013.

13. Статистика: підручник / C. С. Герасименко, А. В. Головач, А. М. Єріна та ін. ; за наук. ред. д. економ. наук С. С. Герасименка. - 2-ге вид., перероб. і доп. - К. : КНЕУ, 2000. - 467 с.

Report of the ISPOR 2012 Budget Impact Analysis Good Practice II Task Force. Value in Health. 2014;17(1), 5-14. Available from: https://doi.org/10.1016/j. jval.2013.08.2291.

7. Josephine A. Mauskopf, Sean D. Sullivan, Lieven Annemans, Jaime Caro, C. Daniel Mullins, Mark Nuijten, et al. Principles of Good Practice for Budget Impact Analysis: Report of the ISPOR Task Force on Good Research Practices - Budget Impact Analysis. Value in Health. 2007;10(5), 336-47. Available from: [https://doi. org/10.1111/j.1524-4733.2007.00187.x]

8. Drug and Therapeutics Committees - A Practical Guide. World Health Organization. 2003; Available from: http:// apps.who.int/medicinedocs/es/d/Js4882e/12.html.

9. Management Sciences for Health and World Health Orf ganization. 2007. Drug and Therapeutics Committee Training Course. Submitted to the U.S. Agency for International Development by the Rational Pharmaceutical Management Plus Program. Arlington, VA: Management Sciences for Health.

10. Pariy VD, Safonov YuM, Zakharova NM, Dumenko TM, Zhula AV, Taran VV., Borus VM, Vezhnovets TA, Matukova DG, Prus NV. Economic analysis of the use of resources in the health system. [Економічний аналіз використання ресурсів в системі охорони здоров'я] Zhytomyr: "Polissia"; 2015. Ukrainian.

11. Morozov AM., Yakovleva LV, Besditko NV. Methodical recommendations for assessing the clinical and economic feasibility of the use of drugs in the health care institution (support of the formular system). [Методичні рекомендації з оцінки клінічної та економічної доцільності використання лікарських засобів у лікувально-профрілактичному закладі (супровід фрормулярної системи)] Kharkiv: NPhU; 2012. Ukrainian.

12. Bidiuk PI, Terentiev OM, Prosiankina-Zharova TI. App plied statistics. [Прикладна статистика] Vinnytsia: "Edelveis \&K"; 2013. Ukrainian.

13. Gerasumenko SS, Golovach AV, Jerina AM, Koo zuriev OV, Palian ZO, Shustiko AA. Statistics: textbook. [Статистика: підручник] Kyiv: KNEU; 2000. Ukrainian.

\section{Відомості про авторів:}

Олещук О. М. - Д. мед. н., профресор, голова Експертного комітету з відбору та використання основних лікарських засобів МОЗ України, завідувач кафедри фрармакології з клінічною фармакологією, Тернопільський національний медичний університет імені І. Я. Горбачевського МОЗ України, Тернопіль, Україна. E-mail: oleshchuk@tdmu.edu.ua, ORCID 0000-0002-1491-1935

Думенко Т. М. - к. мед. н., директор ДП «Державний експертний центр МОЗ України», Київ, Україна. E-mail: dumenko@dec.gov.ua, ORCID 0000-0003-2718-2740

Піняжко О. Б. - к. фрармац. н., директор Департаменту оцінки медичних технологій ДП «Державний експертний центр МОЗ України», член Експертного комітету з відбору та використання основних лікарських засобів мО3 України, Київ, Україна. E-mail: pinyazhko@gov.ua ORCID 0000-0003-1131-733X

ISSN 2312-0967. Фармацевтичний часопис. 2019. № 3 
Романенко І. М. - член Експертного комітету з відбору та використання основних лікарських засобів, начальник відділу оцінки економічної ефективності лікарських засобів Департаменту оцінки медичних технологій ДП «Державний експертний центр МОЗ України», Київ, Україна. E-mail: romanenko_ira@dec.gov.ua, ORCID 0000-00027447-6170

Клименко М. М. - член Експертного комітету з відбору та використання основних лікарських засобів, заступник начальника відділу оцінки економічної ефективності лікарських засобів Департаменту оцінки медичних технологій ДП «Державний експертний центр МО3 України», Київ, Україна. E-mail: mklumenko@dec.gov.ua , ORCID 0000-00018742-2246

Топачевський О. А. - член Експертного комітету з відбору та використання основних лікарських засобів, Київ, Україна. E-mail: topachevskyi.olek@gmail.com, ORCID 0000-0003-4723-9521

Лелека М. В. - канд. фрармац. н., експерт відділу оцінки економічної ефективності лікарських засобів Департаменту оцінки медичних технологій ДП «Державний експертний центр МОЗ України», Київ, Україна. E-mail: Ieleka@dec.gov. ua, ORCID 0000-0002-7364-5614

\section{Information about the authors:}

Oleshchuk O. M. - MD, Professor, Head of Expert Committee on Selection and Use of Essential Medicines MoH of Ukraine, Head of Pharmacology and Clinical Pharmacology Department, I. Horbachevsky Ternopil National Medical University, Ternopil, Ukraine. E-mail: oleshchuk@tdmu.edu.ua, ORCID 0000-0002-1491-1935

Dumenko T. M. - MD, Director of the State Expert Center MoH of Ukraine, Kyiv, Ukraine. E-mail: dumenko@dec.gov.ua, ORCID 0000-0003-2718-2740

Pinyazhko O. B. - PhD (Pharmacy), Director of the Health Technology Assessment Department, State Expert Center MoH of Ukraine, Member Expert Committee on Selection and Use of Essential Medicines MoH of Ukraine, Kyiv, Ukraine. E-mail: pinyazhko@gov.ua ORCID 0000-0003-1131-733X

Romanenko I. M. - Member Expert Committee on Selection and Use of Essential Medicines MoH of Ukraine, Head of the Department for Evaluation of the Economic Efficiency of Medicines of the Medical Technology Evaluation Department, State Expert Center of the MoH of Ukraine, Kyiv, Ukraine. E-mail: romanenko_ira@dec.gov.ua, ORCID 0000-0002-74476170

Klimenko M. M. - member of the Expert Committee on the Selection and Use of Essential Medicines MoH of Ukraine, Deputy Head of the Department for Evaluation of the Economic Efficiency of Medicines of the Department of Medical Technology Evaluation of the State Expert Center of the MoH of Ukraine, Kyiv, Ukraine. E-mail: mklumenko@dec.gov.ua, ORCID 0000-0001-8742-2246

Topachevsky O. A. - member of the Expert Committee on the Selection and Use of Essential Medicines MoH of Ukraine, Kyiv, Ukraine. E-mail: topachevskyi.olek@gmail.com, ORCID 0000-0003-4723-9521

Leleka M. V. - PhD (Pharmacy), expert of the department of evaluation of the economic efficiency of medicinal products of the Department of Medical Technology Assessment of the State Expert Center MoH of Ukraine, Kyiv, Ukraine. E-mail: leleka@dec.gov.ua, ORCID 0000-0002-7364-5614 